\title{
THE CPA FAILURE AND THE CONFLICT IN SOUTHERN KORDOFAN AND BLUE NILE STATES
}

\author{
Benedetta De Alessi ${ }^{1}$ \\ Independent Researcher
}

\begin{abstract}
:
This article examines the conflict emerged in the Sudan's states of Southern Kordofan and Blue Nile between the Government of Sudan and the Sudan People's Liberation Movement/Army - North (SPLM/A-N) in the aftermath of the Referendum for self-determination that led to the separation of South Sudan from Sudan. It makes the point that the conflict in the so-called Two Areas - the North/South border regions of Sudan that fought alongside the SPLM/A during the country's second civil war - is the direct result of the failure of the Comprehensive Peace Agreement (CPA) to address Sudan's issue of sovereignty beyond the north/south divide, both in its design and implementation. As a result of the CPA, neither peace nor democracy was reached in Sudan. The analysis also looks at the question of liberal peacebuilding and its flawed application in the country.
\end{abstract}

Keywords: SPLM, Sudan, Conflict Resolution, Peace-building, Civil War, Peace Agreement, Southern Kordofan, Blue Nile, CPA.

\begin{abstract}
Resumen:
En este artículo se examina el conflicto surgido en los Estados sudaneses de Kordofán del Sur y del Nilo Azul entre el Gobierno de Sudán y el Ejército/ Movimiento de Liberación del Pueblo de Sudán - Sector Norte (MLPS-N) en el periodo posterior al Referéndum de autodeterminación que desembocó en la secesión de Sudán del Sur de Sudán. El artículo incide en que el conflicto en las denominadas Dos Áreas (las regiones fronterizas entre el norte y el sur de Sudán que lucharon junto al E/MLPS durante la segunda guerra civil en el país) es el resultado directo del fracaso del Acuerdo General de Paz (AGP), tanto en su concepción como en su implementación, en cuanto a cómo abordar el tema de la soberanía de Sudán más allá de la división norte-sur. Ni la paz ni la democracia prosperaron en Sudán como consecuencia del AGP. El artículo también analiza la cuestión de la construcción de paz liberal y su aplicación defectuosa en el país.
\end{abstract}

Palabras clave: MLPS, Sudán, resolución de conflictos, construcción de la paz, guerra civil, acuerdo de paz, Kordofán del Sur, Nilo Azul, Acuerdo General de Paz.

Copyright $\odot$ UNISCI, 2013.

Las opiniones expresadas en estos artículos son propias de sus autores, y no reflejan necesariamente la opinión de UNISCI. The views expressed in these articles are those of the authors, and do not necessarily reflect the views of UNISCI.

\footnotetext{
${ }^{1}$ Dr. Benedetta De Alessi is an independent researcher awarded a PhD at SOAS, University of London, in January 2013. She specialises on Sudan, South Sudan and, in particular, the SPLM/A and the SPLM development in the aftermath of the civil war. She is more generally investigating the question of transformation of rebel movements into political organisations in the course of implementation of peace agreements. Her research belongs to the theory of politics and conflict resolution and transformation. She can be reached at bda@soas.ac.uk.
}

http://dx.doi.org/10.5209/rev_UNIS.2013.n33.4481ם 


\section{The CPA and the Two Areas}

In January 2005 the Comprehensive Peace Agreement (CPA) was signed between the Government of Sudan (GoS) and the Sudan People's Liberation Movement/Army (SPLM/A) after two decades of civil war in the largest African country (1983-2005). The war was triggered in 1983 by the abrogation of the Addis Ababa Agreement that had been signed in 1972 between the Government and the southern rebels, the Anya-nya. Despite a decade of relative peace, the Agreement did not answer the demands of the southerners for an even distribution of power and wealth in the country. The autonomous government created in Southern Sudan remained under the direct control of Khartoum. The southern region of Sudan had asked for autonomy since the time ahead of the independence of Sudan in 1956, given the exploitation of its social and economic wealth already under the Anglo-Egyptian condominium, but its representatives were divided over the kind of power sharing arrangements were best for the region and that weakened their demands vis-à-vis the central Government. $^{2}$

In May 1983 a group of southern soldiers in the Sudan army created the SPLM/A. Unlike previous southern rebellions that sought a solution to the 'problem of Southern Sudan' i.e. its political and economic marginalization of the region, the new movement looked at the 'problem of Sudan', thus solvable through the transformation of the center. The rebels put forward the demand for a new Sudan, secular, equal and democratic for all. ${ }^{3}$ The 'New Sudan vision' of the SPLM/A, designed by its first Chairman John Garang de Mabior, attracted the northern marginalized from Southern Kordofan and Blue Nile - the so-called Two Areas examined in this article -, from the contested region of Abyei, from the western region of Darfur and from Eastern Sudan, on top of the urban communists and progressive youth and women groups disgruntled by the new Islamic and military outlook of the regime (President Nimeiri had embraced sharia law and Sudan became an Islamic country with the September laws of 1983). The lack of political space in Sudan had pushed these populations into the SPLM/A rebellion with the aim of achieving a democratic new Sudan. The New Sudan vision was not universally understood within the movement but Garang managed to impose his thought over the separatist drives of other members of the rebellion throughout the civil war. ${ }^{4}$

The leaders of local political parties from the Two Areas - the Nuba Jusif Kuwa and Abdelaziz el Hilu, and the Ingessana Malik Agar - were among the first northerners to join the SPLM/A since 1984. They were instrumental in bringing their population on board and they soon became close aides of Garang. The indigenous tribes of the Two Areas, such as the Nuba in Southern Kordofan and the Ingessana and the Uduk in Blue Nile, had been victim of a process of Islamisation and discrimination perpetrated by Khartoum. The land had been

\footnotetext{
${ }^{2}$ On the history of Sudan see Holt, P.M. and Daly M.W. (2000): A History of the Sudan. From the Coming of Islam to the Present Day, Fifth Edition, Harlow, Pearson Education Limited. The 'Southern question' was examined by two prominent politicians of that time in Oduho, J. and Deng, W. (1963): The problem of the Southern Sudan, London: Oxford University Press. On the Addis Ababa Agreement see the personal accounts of Alier, A. (1990): Southern Sudan: Too Many Agreements Dishonoured, Exeter, Ithaca Press; Khalid, M. (1985): Nimeiri and the Revolution of Dismay, London, Kegan Paul; and Lagu, J. (2006): Sudan: Odyssey through a State, from Ruin to Hope, Khartoum, Khartoum University Press.

${ }^{3}$ SPLM/A manifesto, 1983. The SPLM/A was born under the support of the Eastern Bloc during the Cold War. Its vision, initially nuanced with socialist thoughts, developed in the course of the struggle to embrace liberal western thoughts as it can be noted in the document 'SPLM Vision, Program and Constitution of the New Sudan' of 1998.

4 The birth and development of the movement was full of difficulties as the mutineers disagreed on their objectives and structures, as reported by Arop, M.A (2006): Sudan's Painful Road to Peace. A Full Story of the Founding and Development of the SPLM/A, Charleston, BookSurge.
} 
exploited by the central Government to extract oil, minerals and used for mechanized agriculture without benefiting the local population. The Christian Uduk tribe in Southern Blue Nile, living in an enclave between north and southern Sudan, had been furthermore harassed for religious reasons and displaced. ${ }^{5}$ While the northern peripheries never organized militarily to support the southern rebellion in the North, the population of the Two Areas provided manpower and leadership and thanks to their involvement the SPLM/A occupied territories in the North, namely the Nuba mountains in Southern Kordofan and the southern part of Blue Nile. With their support, the SPLM/A, a southern born rebel movement, became de facto a national liberation movement. ${ }^{6}$

The New Sudan vision gave the SPLM/A international recognition and it led the SPLM/A towards the negotiations with Khartoum. The Parties had exhausted the benefits of the war and signed the CPA also thanks to a massive international support. The Agreement provided for political, security and economic arrangements for the peaceful cooperation between North and South Sudan and their development based on the oil economy. It defined a crucial cease-fire between the two armies, the Sudan Armed Forces (SAF) and the SPLA, and their relocation respectively in the north and south of Sudan. It also set the basis for the drafting of a new constitution and the establishment of joint national institutions to trigger the democratization of Sudan during an interim period of six years during which the Parties would work alongside 'to make unity attractive'.

The southern Sudanese were granted the right to a Referendum for self-determination at the end of the interim period. The Parties ultimately agreed to a 'one-country-two systems' model as a solution to the 'problem of Sudan'. The CPA, a liberal peace agreement, was designed to reach both peace - through the self-determination option and special security arrangements - and democracy during the transition. The SPLM was thus officially constituted as a national political party, to work alongside the ruling National Congress Party (NCP) and realize the dual objective of peace and democracy enshrined in the Agreement. The SPLM was considered 'the engine' of the expected democratization of Sudan. ${ }^{7}$

\footnotetext{
${ }^{5}$ See African Rights (July 1995), Facing Genocide: the Nuba of Sudan, London, African Rights; and James, W. (2007), War and Survival in Sudan's Frontier Lands: Voices from the Blue Nile, Oxford, Oxford University Press.

${ }^{6}$ The SPLM/A had also territories in a small enclave in Hamashkoreb, in Eastern Sudan.

${ }^{7}$ SPLM (August 2004): Strategic Framework for War-to-Peace transition, New Site, Kapoeta County. The transformation of the SPLM/A into the SPLM is examined in the author's PhD Dissertation, De Alessi B. (2013): The War-to-Peace Transition of the SPLM/A into the SPLM during the Implementation of the CPA, PhD dissertation, SOAS.
} 


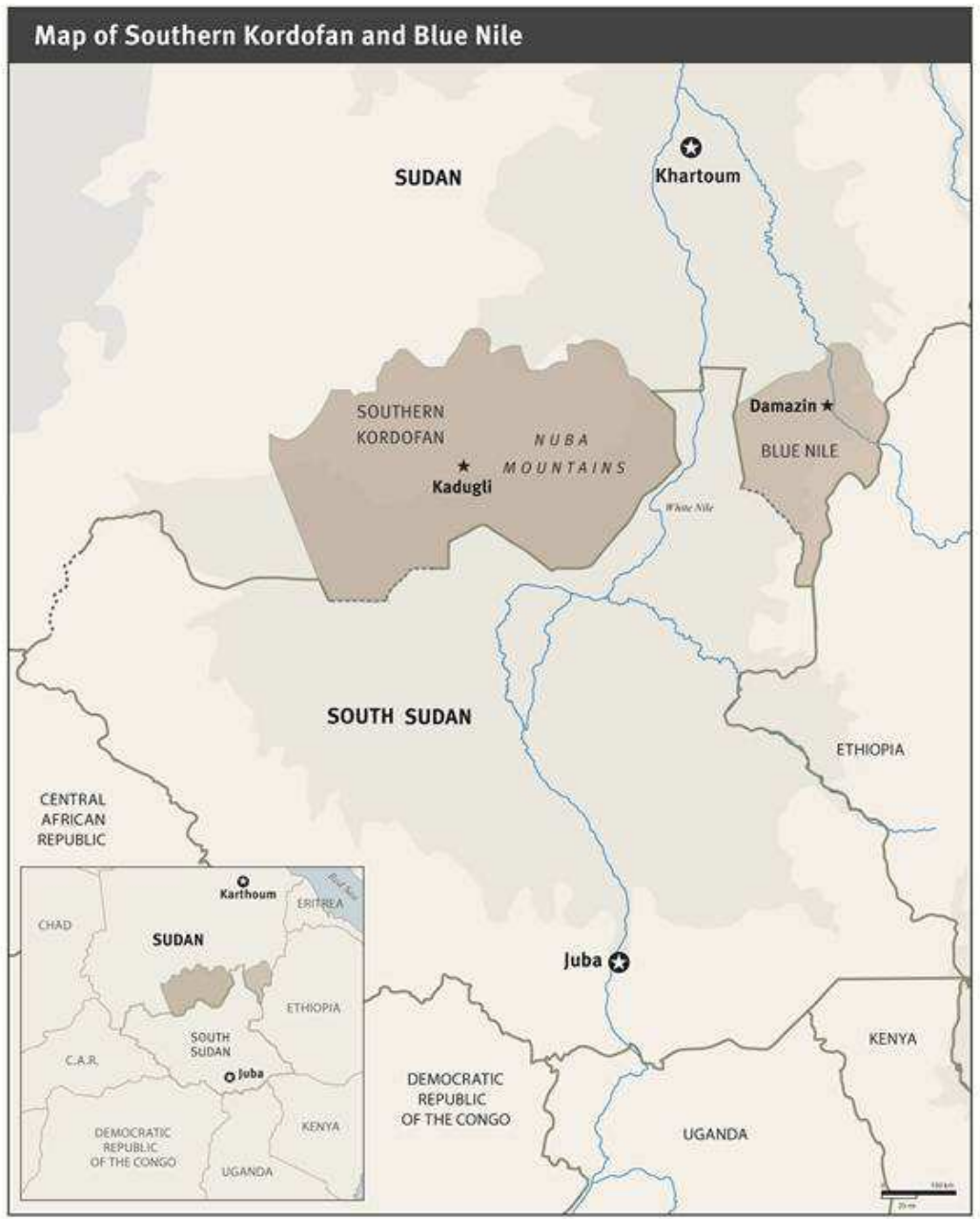

Source: Human Rights Watch, http://www.hrw.org/node/111880/section/2

Despite the declared aim of achieving the New Sudan through the CPA, the design of the Agreement made its realization extremely challenging. Sudan in fact remained an Islamic country while only the southern region obtained to be secular. The Agreement gave in fact special benefits to the major constituency of the SPLM/A, the Southern Sudan - that had grown stronger during the civil war vis-à-vis the northern comrades - with an autonomous government led by the SPLM and defended by its own army, the SPLA, pending the realization of the Referendum. ${ }^{8}$ The plan of realizing the transformation of Sudan through the SPLM at the national level was hazardous. The SPLM/A was in fact a loose political organization during the war and its non-military activities in the North were limited to mobilization of the fighters by youth and women groups working underground.

\footnotetext{
${ }^{8}$ Separatist leaders of the SPLM/A during the civil war architected a coup, the Nasir split of 1991, and created a separatist movement fighting for the separation of Sudan from the North. The move was weakened by internal divisions and broken alliances with Khartoum. The history of the split is reported in Johnson, D. (2011), The Root Causes of Sudan's Civil Wars, Oxford, James Currey. See also the excellent account of one of the participants to the split, Adwok Nyaba, P. (1997): The Politics of Liberation in Southern Sudan, an Insider's View, Kampala, Fountain Publishers.
} 
The opposition in the North and the other marginalized areas moreover were excluded from the negotiations, even if their cooperation was crucial to challenge the monopoly of power of the ruling NCP in the national institutions. According to the opposition, the Agreement signed between GoS and the SPLM/A was 'comprehensive' only in name while it was ultimately a deal between the North and the South and they decided not to endorse it. The rebels from Darfur and the East, at war with Khartoum on issues related to uneven power and wealth sharing with the center, like the South, decided to sign separate agreements after the CPA. ${ }^{9}$ Despite the crucial support that the SPLM/A had given to the upsurge of the rebellion in Darfur in 2003, and the relation built with the opposition in exile through the National Democratic Alliance, at the time of negotiating the CPA the leadership of the movement decided not to include the demands of the other marginalized, revealing furthermore the weakness of the plan to achieve the New Sudan in the design of the CPA.

Given the special role played during the war, the Two Areas were granted special recognition during the negotiations, yet below the expectations of its leadership. In the city of Machakos, Kenya, in 2002, where the basis of the CPA was set, the NCP was initially reluctant to consider the Two Areas in the negotiations claiming that they were part of the North hence not conducive to a solution of the 'Southern problem'. The SPLM/A, that was talking of a problem of Sudan, insisted to discuss the future of Southern Kordofan and Blue Nile and the presence of representatives of those areas in the negotiating team reinforced that stance. The discussion remained focused on the North/South axis only, but a landmark ceasefire was signed in the strategic Nuba Mountains in 2002, thanks to the US support. The international community and the US in particular had become keener to deliver peace in Sudan in the aftermath of the attacks of 11 September 2001 and to gain a strategic ally in the region in their War of Terror. Ultimately, the NCP was convinced to include the Two Areas in the discussion in Naivasha as part of the recognition of Sudan diversity and the right for economic, social and cultural development of all citizens, particularly of the war affected areas, brought by the CPA. The Two Areas were eventually seen as a model for the peaceful and prosperous cooperation between the SPLM/A and the NCP in the development of Sudan as a united country. ${ }^{10}$

The 'Protocol for the resolution of the conflict in Southern Kordofan and Blue Nile States' was signed on 26 May 2004. ${ }^{11}$ It granted special economic, security and political arrangements to those war affected areas that had fought alongside the SPLM/A but were not under the jurisdiction of the SPLM (during the war the area called by the SPLM/A Southern Sudan had included the Two Areas, to form the so-called New Sudan, but according to the official maps of the country the areas were above the North/South border). The Parties agreed

\footnotetext{
${ }^{9}$ The rebels in the East signed the Eastern Sudan Peace Agreement (ESPA) with Khartoum in 2005 that brought their representatives to the Government, without however putting an end to the severe underdevelopment of the area. The Darfur Peace Agreement (DPA) was signed in 2006 but it did not lead to a solution of the conflict given the divisions among the rebels and the little representation of the signatories on the ground.

${ }^{10}$ Alongside the Two Areas, the discussion was also on the area of Abyei, a strategic region rich of oil contested between the North and the South. The Three Areas, or Transitional Areas, became pivotal in the negotiations. Abyei however was granted the right to self-determination like the Southerners, while the Two Areas were considered strictly part of the North. Abyei had already been recognised a special status in the Addis Ababa Agreement and the right to the people of Abyei to a Referendum to decide, however, only whether they were to be administered by the North or the South. The discovery of the oil in the late 1970s provoked a sudden shift of interest from Khartoum towards the region and that provision was disregarded, in Alier A., op.cit. The Protocol of Abyei is not examined in this article. For an analysis see Johnson, D.: "Why Abyei Matters: the Breaking Point of Sudan's Comprehensive Peace Agreement?”, African Affairs, Vol. 107, No 426 (2007), pp. 1-19.

${ }^{11}$ The Southern Kordofan indicated in the Agreement comprised of the areas in the Nuba Mountains held by the SPLM/A during the war and part of the former Western Kordofan State.
} 
to a rotational governorship between NCP and SPLM every three years and 55\% to NCP and $45 \%$ to SPLM in the State Legislatures, and the equal presence of the two armies, the Sudan Armed Forces (SAF) and SPLA, in Joint Integrated Units (JIUs) dislocated in the States (the JIUs were also present around Southern Sudan and in Khartoum). They also obtained ad hoc funding mechanism through the National Reconstruction and Development Fund (NRDF), dedicated to the northern war affected areas, given that they had been badly damaged in the twenty years of conflict. Southern Kordofan was, moreover, entitled to $2 \%$ of oil revenues as a producing State. The Protocol was recognizing the strategic importance of those areas for both Parties, both economically and militarily. Peace in the Two Areas was essential for the tenure of the CPA.

The Parties also agreed to a right to a popular consultation process, a democratic mechanism 'to ascertain the view of the people of the States on the CPA implementation' (Protocol, 3.1). The implementation was to be carried out by the elected State Assembly, thus after the General Elections expected in 2008, tasked to collect the views of the population over the CPA and to put forward their demands to the central Government. The process was a compromise and as such, badly defined in the CPA, leaving room to different interpretations by the Parties. The leaders of the Two Areas wanted the right to self-determination, like Abyei and South Sudan, but the NCP could not agree to it. Garang convinced the local leaders to accept the compromise, ensuring them that the CPA would result in the unity of Sudan and through the popular consultation the Areas would obtain more benefits than any other state in the country. The extent of it remained a question mark i.e. could the population ask for an autonomous local government? The weakness of the new Sudan vision in the design of the CPA, as discussed, was making the possibility for the Two Areas to become a model for the new democratic country more challenging. ${ }^{12}$ The implementation time was then for the SPLM a crucial test.

\section{The Loose Implementation of the Agreement in the Two Areas}

Through the CPA Sudan achieved peace, but the plan of realizing democracy in the country in the interim period depended on the commitment of the two Parties to it. The death of the SPLM/A Chairman John Garang, the architect of the CPA, in July 2005 and the advance of the separatist leaders of the SPLM/A led by the new Chairman Salva Kiir - that provoked also the sideline of Garang's aides who believed in the new Sudan vision, including the Nuba leader Abedelaziz el Hilu - was crucial to the debacle of the transformative project enshrined in the Agreement. The death of the Chairman in fact weakened the commitment towards a New Sudan of both the SPLM and the NCP during the interim period. It also revealed the little adherence to the plan of a united Sudan within the Parties.

The SPLM's transformation into a national political party lagged behind and the powerful position of the NCP remained unchallenged, also thanks to the lack of opposition in Parliament. The SPLM/A leadership focused on the reconstruction of Southern Sudan and the building of the new autonomous executive and military institutions in the region devastated by the war. The focus went on the conservation of peace i.e. the cease-fire with Khartoum, in order to reach the Referendum and the independence of South Sudan. The implementation of the CPA, led by the signatories of the CPA, GoS and the SPLM/A, became a technical and

\footnotetext{
${ }^{12}$ These paragraphs are the result of interviews conducted by the author with local leaders and CPA mediators in Juba between December 2010 and February 2011 and extracted from De Alessi, op.cit.
} 
selective matter while the space for political debate was limited. The Parties were maintaining their cooperation at the minimum level and in several occasions the Agreement was about to collapse. The CPA institutions were weakened by the tense relationship between the Parties and often made ineffectual (it is the case of the North/South border commission that worked under tremendous pressure and never managed to define a line due to the presence of oilfields and mineral reserves along the border, contested by the Parties). Crucial steps for the transformation of the country, such as the National Population Census and the General Elections, were implemented only as necessary steps to achieve the end of the interim period through a peaceful Referendum. The CPA brought a fragile no-war-no-peace situation that the Parties had to carefully maintain. ${ }^{13}$

The implementation of the Protocol of Two Areas, on top of its structural weakness, was affected by the overall ill implementation of the CPA and the tense relations between Juba and Khartoum. The weakness of the overall project of a new united Sudan enshrined in the CPA became evident. Rather than a model for the development of the new democratic Sudan, the implementation of the Protocol of the Two Areas revealed the weakness of the New Sudan vision in the CPA and among its signatories. The sense of unfair treatment felt in Naivasha was reinforced during the interim period vis-à-vis the implementation of the peace deal that was lining towards the realization of the Referendum against the democratization of the whole country.

A non-functioning NRDF - alongside other funds defined by the Agreement - affected the possibility of the socio-economic development of these war-affected areas. The lack of improvement in the lives of the people in Southern Blue Nile state, which had been severely affected by the conflict, was particularly striking during the interim period. Moreover, due to the high level of mistrust between the Parties both armies, SAF and SPLA, maintained their troops outside the JIUs, revealing the strategic importance of the Two Areas in the relation between North and South during the transition.

The SPLM in the Two Areas was affiliated to the southern sector of the party. The two sectors had been created after the signing of the CPA for administrative reasons: the southern one to develop the party in the liberated territories from the existing SPLM/A institutions while the northern sector was to begin the formation of the new party from scratch in the rest of Sudan. While the role of the former was mainly administrative, the latter had a crucial political function to challenge the NCP in its own constituencies and enter peacefully new territories when the SPLA could not make it. The secretariats of Blue Nile and Southern Kordofan, hampered by the affiliation with the southern comrades, started acting more independently from the rest of the national party in their daily confrontation with the NCP. During the 2010 General Elections, when the SPLM withdrew from the northern context, the leaders of the Two Areas decided to run and, for the first time, the real power of the NCP and the SPLM in the state was tested. The SPLM leader Malik Agar eventually won the Governorship race, while the NCP obtained the majority of seats in the local Parliament. The SPLM also obtained eight seats in the National Assembly, and that will be the only representation of the SPLM northern constituencies. The State Elections in Southern Kordofan were postponed when the local SPLM obtained a recount of the census that had given an unfair representation of the Nuba population in the State. The census result had been

\footnotetext{
${ }^{13}$ The definition is taken from Mac Ginty R. (2006): No War, no Peace: The Rejuvenation of Stalled Peace Processes and Peace Accords, New York: Palgrave Macmillan.
} 
contested also in Southern Sudan but the party decided to accept the result and wait for a recount only after the holding of the Referendum.

As a result of late Elections, the conduction of the crucial process of popular consultations in the Two Areas was pushed towards the end of the interim period, missing its function of correcting the implementation of the CPA in the mid interim period. As such, the process conflicted with the political tension between the North and the South around the Referendum time and Khartoum was afraid that the States would demand the right to selfdetermination as well. In Blue Nile the process started in September 2010 with a massive popular participation that was asking for the reforms that did not materialize through the CPA and a degree of autonomy from Khartoum (the dam on the Blue Nile in the capital Damazin, the main source of power for Khartoum, was controlled by the Government and the mechanized farming schemes by foreign investors). The process showed for the first time a state population united against the center, overcoming the Arab versus African polarization built during the civil war. The Government however obstructed the process through dilatory tactics (the collaborative Chairman of the special commission in charge of the process was changed and the release of funds was slow) that had been common during the interim period of the CPA.

In Southern Kordofan the state elections were postponed to May 2011, pending the recount of the local census, and the popular consultation was expected to begin soon after. The NCP's candidate was the incumbent Governor Ahmed Haroon, ICC indicated for war crimes committed in Darfur on behalf of the Government; Abdulaziz al Hilu, one of the leaders of the SPLM and promoter of the New Sudan vision, was contesting for the SPLM. The elections were conducted in an extremely tense environment. For the SPLM the victory in the State was crucial to obtain a better representation in Sudan after the separation from South Sudan (the SPLM southern representatives had left the National Assembly in April 2011). The SPLM from Juba supported the party in the North, keen to have an ally in the strategic border region.

For the ruling NCP, the control of Southern Kordofan was equally essential in its relations with Southern Sudan and for the exploitation of its oil fields. When the NCP won the Elections, the SPLM contested the result and the rigging of the NCP and decided remained in the opposition. The climate was extremely volatile in the aftermath of the vote, also due to the presence of both SAF and SPLA soldiers in the State. In the aftermath of the CPA not only democracy, but also peace, was at stake in Sudan. ${ }^{14}$

\section{The Conflict in Southern Kordofan and Blue Nile States as a Legacy of the Second Civil War}

In February 2011 the independence of South Sudan became a reality after the majority of the southerners had voted in the Referendum for the separation from Sudan. The result was expected after the General Elections in 2010 had given the majority of the seats to the NCP and the SPLM respectively in North and Southern Sudan, marking the de facto separation of powers between the signatories of the CPA in their constituencies ahead of the end of the interim period. The opposition was defeated and remained out of Parliament. The SPLM

\footnotetext{
${ }^{14}$ A similar analysis can be made for South Sudan, where the democracy and peace realised after the General Elections of 2010 were questionable, but it is not part of this discussion.
} 
divided itself in the SPLM-North, an opposition party in Sudan led by the leaders of the Two Areas, while the southern comrades of the SPLM remained in power of the new Republic of South Sudan. The SPLA became the official army of South Sudan and it had to withdraw from the North, while the JIUs were to be dismantled. The critical security question of the northern soldiers of the SPLA i.e. the around 40,000 men from Two Areas who had fought with the SPLM/A during the civil war remained open. The popular consultation process should have discussed whether these soldiers wanted to be demobilized or integrated into SAF and the modalities of that process. The issue then converged into the negotiations between the North and the South over the CPA outstanding issues and other matters to favor an amicable separation of the two countries begun in Addis Ababa since July 2010. ${ }^{15}$

While negotiations were ongoing between Sudan and South Sudan, in June 2011 Khartoum tried to forcibly disarm the SPLA soldiers in Southern Kordofan, claiming that the matter pertained to the North and it could not be part of the discussion with South Sudan. The move, on 5 June 2011, provoked a fight in a barrack in Kadugli (capital of Southern Kordofan) between SPLA and SAF soldiers that quickly escalated into violence across the State. The ground of dissent in the State was high particularly after the lack of any popular consultation process and a contested electoral process. In Southern Kordofan moreover the coexistence of Arab and African population allied during the war respectively to Khartoum and Juba, had created tension throughout the interim period. ${ }^{16}$ The reasons that had pushed the Nuba to join the SPLM/A two decades earlier, the socio-economic marginalization and the centralization of power of the Islamic regime, were still valid after the separation of the Southern region from the North.

Attempts of negotiations began during the summer between GoS and the SPLM/A-N while the conflict was expanding throughout the State. A political solution was found on 28 June 2011 when the Parties signed the Framework Agreement on political and security arrangements for Southern Kordofan and Blue Nile States based on the CPA democratic principles set in Machakos. The Agreement reiterated the importance of the democratic principles for Sudan set in the CPA and the Parties agreed to discuss further political and security arrangements. The Agreement, signed by a senior NCP official, was however repudiated by the President of Sudan and never implemented. In September 2011 Khartoum tried to forcibly disarm soldiers in Blue Nile State and that was a point of no return. Like two months earlier in Southern Kordofan, the move triggered a conflict throughout the State. The SPLM-N elected Governor escaped to Kurmuk, the head quarter of the SPLM/A in the southern part of the State during the war, while his house was attacked in Damazin. Members of the party remained in the State capital were arrested and persecuted. The SPLM-N, a registered political party, was banned from Sudan and it reconstituted itself as a rebel movement, the SPLM/A-North, to fight against the military Ingaz (salvation) regime that the

\footnotetext{
${ }^{15}$ On 2 June 2010 in Mekelle, Ethiopia, the NCP and the SPLM - representing respectively the Government of Sudan and of South Sudan - had met to discuss post-Referendum issues and arrangements and the outstanding CPA issues considering both scenarios of Unity or Separation. Negotiations were led by a NCP-SPLM Joint Negotiation Team with six members each side, mainly the negotiators of Naivasha, and facilitated by the African Union High-Level Implementation Panel (AUHIP) - the body had been at first formed in the context of the Darfur crisis. The Parties agreed on a Road Map for negotiations up to the end of 2010 to create conducive environment for the Referendum. Talks started in July 2010 divided in four groups to address issues concerning Citizenship (nationality, public service), Security (JIUs, National Security and intelligence), International treaties and Agreements and Finance, Economic Issues and Natural Resources (Oilfields, oil production, transport and export of oil, contracts and environment in the oil fields, water, currency, Debts and Assets).

16 ICG: "Sudan's Southern Kordofan problem: the next Darfur", Africa Report, n¹45, International Crisis Group, 21 October 2008.
} 
CPA had left unchanged. ${ }^{17}$ In the aftermath of the CPA, political space in Sudan was limited, a situation similar to that in the aftermath of the Islamic coup that brought the current regime to power in 1989.

The SPLM/A-N allied with the Sudan Liberation Movement/Army (SLM/A) from Darfur, at war with Khartoum since 2003, and with northern political opposition and formed in September 2011 the Sudan Revolutionary Front (SRF), fighting for the democratic transformation of the Sudanese state. A decade later, after a failed peace deal and without the Southern Sudanese, Sudan is once more the theater of a civil war fought between the central regime and its marginalized peripheries. The internal divisions among the group, however, in particular over the religion question and the ideal form of Government in Sudan, weakened the SRF in its political and military fight against Khartoum that has so far refused to negotiate (a situation that reminds of the difficulties of the struggle of NDA during the second civil war).

The Government also discarded the demands of the SPLM/A-N for an even power and wealth sharing in the Two Areas that were endorsed in the Framework Agreement of 2011. Instead, the question of the Two Areas is seen as an obstacle for the successful solution of the problems between the North and the South. Sudan accuses the SPLM, the ruling party of the new Republic of South Sudan, of harboring the former comrades of the SPLM/A-N in Juba and requested the President Salva Kiir to deliver the rebel leaders to Khartoum as a precondition for successful North/South talks. The SPLM rejected the claim and accused in turn Khartoum of sponsoring the ongoing violence in the eastern region of Jonglei in South Sudan, using local rebels as proxy militias (a tactic common during the second civil war). The ongoing tensions between Sudan and South Sudan is thus diverting the attention from finding a solution to the war in the Two Areas, and more generally, to the 'problem of Sudan'. The fate of the Two Areas, and the democratization of Sudan, is once more sacrificed for the tenure of the North/South fragile relations. As a result of the CPA, in fact, not only peace in Sudan but also between the newly born Sudan and South Sudan is at stake.

The conflict in Southern Kordofan and Blue Nile States has provoked in the last two years massive displacement and the long term socio-economic disruption of the local population. While Khartoum downplays the effect of the conflict, according to the SPLM/A$\mathrm{N}$ humanitarian wing, over one million people are affected by the conflict and live as IDPs with limited food, water and health services. Around 200,000 people sought refuge in Southern Sudan. ${ }^{18}$ While the latter receive international assistance, the support to the IDPs is impeded by the Government. The conflict is moreover leaving long term consequences on the lives of the people in the Two Areas with the majority of primary and secondary schools remained closed in the past two years. Human rights international agencies reported the damages provoked by the constant aerial bombing of the civilians from the side of the

\footnotetext{
${ }^{17}$ Mohamed Salih, Z.: "From impasse to the brink of war: Sudan bans SPLM-North", 7 September 2011, at http://www.theniles.org/helper/articleprint.php?id=1024

${ }^{18}$ The figures of the situation in the States are provided by the Sudan Relief and Rehabilitation Agency (SRRA), in SRRA's Special Report on The Humanitarian and Human Rights Situation of the IDPs and War Affected Civilians in the SPLM/A-North Controlled Areas of Southern Kordofan and Blue Nile States, December 2012. It is said that in southern Kordofan, the estimated population living in the SPLM-N areas is about 995,200; of which 436,157 are internally displaced. It is assessed that about 736,329 were vulnerable and in need of assistance. In Blue Nile the total population residing in the SPLM-N held areas is about 80,147, of which 64,550 were IDPs. The estimated vulnerable population in Blue Nile is about 73,781 persons. The numbers of the refugess are provided by UNCHR and can be found online.
} 
Government, confirmed by satellite imagines, and the severe human rights violations. ${ }^{19}$ The international community initially hesitant to condemn Khartoum in order to avoid a collapse of the Sudan/South Sudan talks, it has now publically denounced the use of violence against civilians but, unlike a decade ago, it has no leverage on the regime.

\section{The CPA and the Failure of Liberal Peacebuilding in Sudan}

The case of Sudan can be analyzed through the recent scholarships that reveal the failure of liberal peacebuilding in the Third World. From the end of the Cold War the use of liberal peace agreements has become common to 'end' a civil war, in the African continent and elsewhere despite its effectiveness. A liberal peace agreement links the idea of liberal peace of peace tied to development to avoid a relapse into conflict promoted by the United Nations ${ }^{20}$ - to that of liberal democracy, the procedural democracy based on electoralism, multi-party democracy, marketization, and generally institutionalization. ${ }^{21}$ In the aftermath of the attacks of 11 September 2001 on the US, liberal peace - also called democratic peace more increasingly combined and conflated 'liberal', in political and economic tenets, with 'peace', the policy predilection towards conflict resolution and social reconstruction and peacebuilding developed into statebuilding to respond to global imperatives of maintaining the modern state system. ${ }^{22}$

The initial optimism that supported the exercise of liberal peacebuilding in the Third World was corroborated by figures produced by practitioners. The Human Security Report (HSR) in 2005 reported that thanks to the use of peace agreements the number of conflicts worldwide declined from the end of the Cold War. The Human security Brief of 2007 analyses 'the extraordinary, but largely unnoticed, positive change in sub-Saharan Africa's security landscape' where the number of conflicts more than halved between 1999 and 2006 and the combat toll dropped by $98 \%$ cent. According to the HSR of 2009, peace-making constitutes a plausible explanation for the $77 \%$ decline in the high-intensity civil conflicts. ${ }^{23}$ Liberal peace agreements became the symbol of the mechanical and de-contextualized implementation of democratic peace as a normative ideal, against the complexity of 'new wars' encountered on the ground. ${ }^{24}$ Their use was justified by a liberal optimism which

\footnotetext{
${ }^{19}$ Amnesty International (2013): Sudan: 'We had no time to bury them': War crimes in Sudan's Blue Nile state, London, Amnesty International, at

http://www.amnesty.org/fr/library/asset/AFR54/011/2013/en/96b0c8a7-55aa-4f04-8ab7cf85ce3e4c8f/afr540112013en.pdf.

The report also analyses the increasing militarisation of the refugee camps in Southern Sudan by the SPLM/A-N. See also Human Rights Watch (2012): Under siege: Indiscriminate Bombing and Abuses in Sudan's Southern Kordofan and Blue Nile States, Human Rights Watch, at http://www.hrw.org/reports/2012/12/12/under-siege.

${ }^{20}$ The UNSG Boutros-Ghali issued the UN Agenda for peace in 1992, followed by the UN Agenda for Development of 1994 delivered by the following UNSG, Kofi Annan.

${ }^{21}$ Paris, R. (2004): At War's End: Building Peace after Civil Conflict, Cambridge, Cambridge University Press.

${ }^{22}$ Duffield, M. (2007): Development, Security and Unending Wars: Governing the world of peoples, London, Polity.

${ }^{23}$ The Human Security Reports and Briefs since 2005 are available online at http://www.hsrgroup.org.

${ }^{24}$ The point is made by Duffield, M. (2001): Global Governance and the New Wars: The Merging of Development and Security, London, Zed books; and Spears, I. (2000): "Understanding Inclusive Peace Agreements in Africa: The Problem of Sharing Power", Third World quarterly, vol. 21, No 1 (2000), pp. 105118. Duffield examines the security tied to development that leads to the extreme outcome of statebuilding developed in the last decade. On the concept of 'new wars' see Kaldor, M. (2006): New and Old Wars: Organized Violence in a Global Era, 2nd edition, Cambridge, Polity Press. The dilemma of statebuilding was
} 
allows for a subjective and short term evaluation of the performance limited to the creation of the institutions provided for in the agreement i.e. the Weberian State, despite their effectiveness. $^{25}$

Quantitative research carried out at the beginning of this century revealed the weakness of the liberal peacebuilding approach. Research conducted with a longer timeframe showed that while there has been a decline in conflicts since the Cold War, the manifestation of armed conflicts in 2006 was still roughly twice as it was in $1946 .{ }^{26}$ The wave of positivism was furthermore tempered by the realization of the fact that conflicts that terminate with a negotiated settlement are generally more prone to failure. A study on peace agreements signed between 1989 and 2005 reveals that $40 \%$ of conflicts ended through a negotiated settlement restored to violence within five years. More so, within the range of peace agreements the liberal type is more failing. ${ }^{27}$

The literature of conflict resolution started acknowledging that the determination of success of an agreement is often short-termed and focuses on the technical implementation of provisions rather than the internal social dynamics (security reform, market liberalization and electoralism i.e. a timely conduction, the formation of ad hoc institutions regardless of their functioning). ${ }^{28}$ The de-politicization of 'peace' and 'conflict' under liberal assumptions allows for the reproduction of universal and technical solutions, disregarding local power relations, politics and history - reproducing what Adorno called the 'administrated state' in a vacuum - hence missing the goal of sustainable peace and democracy. ${ }^{29}$ Heathershaw shows that the peace sought for in liberal peacebuilding is no longer a social event but the result of conflict practices and therefore is not sustainable. ${ }^{30}$

Evidence coming from Africa corroborates those finding; the number of conflicts in the continent increased since the 1990 and conflicts mainly emerged from a failed resolution of the previous ones. ${ }^{31}$ Peace agreements in fact tend to freeze local dynamics to force social conflict into those patterns that are easily understood through liberal codes; instead as most African states are trapped in a circle of underdevelopment which stimulates societal conflicts,

studied by Sisk, T. and Paris, R (eds.) (2009): The Dilemmas of Statebuilding: Confronting the Contradictions of Postwar Peace Operations, London/New York, Routledge. See also Chandler, D.: "The Responsibility to Protect? Imposing the 'Liberal Peace'”, International Peacekeeping, Vol. 11, No. 1 (Spring 2004), pp. 59-81.

${ }^{25}$ De Alessi, op.cit. Kriger, N. (2003): Guerrilla Veterans in Post-war Zimbabwe, Cambridge, Cambridge University Press, studied the long-term disastrous effects of the Lancaster agreement in Zimbabwe, at first considered successful, when the veterans' war emerged a decade later. Cramer, C. (2006): Civil War is not a Stupid Thing: Accounting for violence in developing countries, London, Hurst \& Co, questioned the idea of success of Mozambique agreement of 1992 based on recent development of the local economy. Reilly, C. A. (2009): Peace-Building and Development in Guatemala and Northern Ireland, New York, Palgrave Macmillan, emphasized the weakness of the temporary dimension of peacebuilding.

${ }^{26}$ The UCDP/PRIO data base is available at http://www.prio.no/CSCW/Datasets/Armed-Conflict/UCDP-PRIO/; the changes in the last annual update are in Harbom, L. and Wallensteen P.: "Armed Conflict, 1946 - 2010 ", Journal of Peace Research, Vol. 48, No. 4 (July 2011), pp. 525-536.

${ }^{27}$ Harbom, L. and Wallensteen P.: "Armed Conflict, 1989 - 2006", Journal of Peace Research, Vol. 44, No 5 (September 2007), pp. 623-634.

${ }^{28}$ On the limits of DDR see Berdal, M. (1996): Disarmament and demobilization after civil wars: Arms, soldiers, and the termination of conflict, Adelphi paper no. 303, Oxford, Oxford University Press.

${ }^{29}$ The point is elaborated by Darby, J. and Mac Ginty, R. (eds.) (2003): Contemporary Peacemaking: Conflict, Violence and Peace Processes, Basingstoke, Palgrave Macmillan.

${ }^{30}$ Heathershaw, J.: "Unpacking the Liberal Peace: The Dividing and Merging of Peacebuilding Discourses", Journal of International Studies, Vol. 36, No. 3 (May 2008), pp.597-621.

${ }^{31}$ De Waal, A. (ed.) (2002): Demilitarizing the mind. African agendas for peace and security, Justice Africa, Africa World Press. 
the liberal agenda confronts 'massive challenges to its successful realization' ${ }^{32}$ External attempts to export replicas of Western liberal democratic states can repress popular accountability thus state legitimacy in the eyes of their citizens with the adverse effect of undermining sustainability of peace and the democracy sought for. ${ }^{33}$

The case of Sudan's CPA proves the findings of recent scholarship on the flawless of liberal peacebuilding applied to the African context. The CPA was a complex agreement based on the predicaments of liberal democracy that were de-contextualized from the situation in Sudan after two decades of civil war. The CPA failed to address the issue of uneven power and wealth sharing in the country, while urging the Parties to deliver democracy through the conduction of General Elections in the mid interim period (the NCP and the SPLM did not want Elections but were convinced by the mediators). The full CPA implementation, for the democratic transition of Sudan, was based on the commitment of the NCP and the SPLM that at the time of signing the Agreement were not national democratic political parties. The signatories of the CPA used the Agreement to their interest: the deal is in fact fore and foremost a bilateral deal between the ruling party and the SPLM/A to ensure peace between the north and south Sudan and the development of the two regions based on the oil economy. It came in fact in a moment in time when the Parties had reached what Zartman defined 'a hurting stalemate' and neither could defeat the enemy militarily. Given the little commitment of both Parties to the transformative idea enshrined in the Agreement, more so after the death of the SPLM/A Chairman, John Garang, its implementation became a technical and selective matter conducive to the realization of the Referendum for the self-determination of the Southern Sudanese, at the expenses of the democratization of the country. Peace and democracy became dichotomist ideals, contravening the liberal peacebuilding theory.

\section{Conclusion}

The conflict in the Two Areas emerged in the aftermath of the Referendum for selfdetermination that led to the separation of South Sudan from Sudan, shows that a result of the CPA neither peace nor democracy were reached in Sudan (and also in South Sudan and between the two countries but that was not analyzed in this article). The conflict in the Two Areas was triggered on June 2011 by security matters unresolved by the CPA but it has its roots in the Sudan's history of socio-economic imbalances of the peripheries originated from the time before the independence of the largest African country, and that the peace deal could not correct. After the transitional period, the military regime in Khartoum was reinforced and the marginalized peripheries that had not gained from the CPA, resurrected the use of arms against marginalization, pushed by the same reasons that had triggered the first and second civil war in Sudan.

\footnotetext{
${ }^{32}$ Luckham, R. (2004) quoted in Taylor, I.: "What Fit for the Liberal Peace in Africa?", Global Society, Vol. 21, No. 4 (October 2007), pp. 553-66, p. 559.

${ }^{33}$ Francis, D. J.(ed.) (2008): Peace and Conflict in Africa, London, Zed Books, pp. 12-16.
} 